forthcoming in Analysis

\title{
Actual Consciousness
}

\section{By TED HONDERICH}

Oxford, UK: Oxford University Press, 2014. 432pp. £30.00

1. Actual Consciousness is a critical analysis of and investigation into the nature of consciousness. In it, Ted Honderich addresses and ultimately rejects most extant accounts of consciousness. This must have been a difficulty book to write. Unfortunately, it is also a difficult one to read. Whatever its merits may be, brevity and straightforwardness aren't amongst them.

Honderich's starting place is the 'primary ordinary sense' of consciousness (3): that is, consciousness as we ordinary think of it. Natural as it may seem, such a starting place is not without its problems. Who is the 'we' who thinks of consciousness in this ordinary, primary way? Can such a 'we' be properly delineated? And is there really a primary sense of consciousness, one that both deservers to be the focal point of a philosophical investigation and matches the ordinary conception or meaning of consciousness? But let us set such questions aside.

Consciousness as we ordinarily think of it, Honderich tells us, consists of three 'sides' (3 4, 15, 196, 299, 337): there is perceptual, cognitive, and affective consciousness. Furthermore, Honderich insists that consciousness, ordinarily understood, ought to be clarified as actual consciousness: what it is for one to be conscious amounts to something's being actual. The main goal of the book is to make intelligible and precise such a claim. It aims to do so by setting out to answer the following two questions: (i) What is actual in perceptual, cognitive, and affective consciousness? (ii) What does it mean for something to be actual? Honderich wants to vindicate his actualist account of consciousness by showing that it captures the ordinary understanding of consciousness. He also wishes to expose the shortcomings of alternative, competing accounts of consciousness. Actual consciousness is not just one answer to the question 'What is consciousness, ordinarily understood?' In Honderich's eyes, it is the only viable answer.

2. A rather large part of the book is devoted to setting up the stage for Honderich's actualist account of consciousness. Chapter 2 consists of a critical examination of what Honderich calls the 'five leading ideas about consciousness' (17). These are qualia, what it is like, subjectivity, intentionality, and phenomenality (the last one is Honderich's term 
denoting the conjunction of all the characteristics typically ascribed to phenomenal consciousness). Honderich finds many faults with the different and numerous explications of these ideas as they are advanced in the relevant literature. Some are deemed to be inadequate as characterizations of ordinary consciousness. Some are too vague. Others are not general enough. Some are unhelpful. And some are circular (viciously, I suppose). Chapter 2 ends on a note that if it were true many would find distressing. "The five ideas ... are no good starts or premises for a satisfactory theory of consciousness..." (50).

In chapter 3, Honderich returns to the five leading ideas of consciousness but this time with the aim of determining whether these ideas contain in themselves elements of truth. By revisiting these ideas, Honderich collects 'data' concerning consciousness (68ff.): facts or claims that any adequate theory of ordinary consciousness ought to accommodate. A lengthy and somewhat heterogeneous list of these data is provided (67-8). Honderich here flirts with what Freud called 'narcissism of small differences.' If there is value in those five ideas of consciousness - indeed, if it is through an examination of those ideas that one can uncover characteristics of consciousness-, then why harshly criticize and reject them as confused, false starts?

Chapters 4 and 5 are encyclopedic in their scope. They survey an astoundingly and perhaps unnecessarily large number of differing approaches to consciousness. Here is a (non-exhaustive!) list of positions that are rejected by Honderich: dualism, abstract functionalism, physical functionalism, anomalous monism, the distinction between phenomenal and access consciousness, representationalism, panpsychism, neutral monism, biological naturalism, eliminative materialism, and higher-order theories of consciousness. The stated aim of these two chapters is to raise doubts regarding the success of alternative approaches to consciousness (146) and to prepare the ground for Honderich's own analysis of consciousness. The achieved aim of the chapters is, unfortunately, something else. Most of the positions that Honderich discusses and rejects do not get a fair hearing. Indeed, some of them are, dare I say, roughly drawn caricatures. If these chapters are meant to build the structure upon which Honderich's own account of consciousness can be secured, then the chapters cannot serve that aim. One doesn't erect theories upon half-burnt, still simmering, straw men.

3. Chapter 6 is an oasis in the book. The chapter does a masterful job in describing and summarizing the different conceptions of 'physical' and explicating the meaning of 'objective.' The findings of chapter 6 are put to use in subsequent chapters. In chapters 7 and 8 Honderich focuses on perceptual consciousness and develops a distinction between two ways of being physical: objectively physical and subjectively physical. The distinction between these two ways of being physical (or between two 'worlds' [192-3, 315]) is the 
linchpin of Honderich's project. It allows Honderich to hold that perceptual consciousness is physical but not objectively physical. Being conscious consists in something being actual, Honderich tells us repeatedly (xiii, 53, 69, 83, 118, 191, 207). In the case of perceptual consciousness we now learn that what is actual is 'things having properties': e.g., 'walls, a desk, drawings, shelves of book' (204). 'PP]erceptual consciousness,' Honderich adds, 'is nothing less than something outside of you, a piece of reality out there' (233). The extreme externalist air that such a pronouncement carries is both dissipated and obfuscated by Honderich's explication of what it means for things to be actual in the case of perceptual consciousness. What it is for those items (e.g., desks, rooms, tables) to be actual is that they are physical and subjective: they are parts or pieces of subjectively physical worlds (192). Such worlds are subjective insofar as they are, inter alia, private (227) and non-separable from and dependent on consciousness $(227,231)$. They are physical insofar as they are, inter alia, located in space and time (221f., 231) and dependent both on the objective physical world and on facts about perceivers $(223,244)$.

A similar story is told with regards to cognitive and affective consciousness (chapters 9 and 10). What is actual in those types of consciousness is respectively representations affirmed and representations valued. What it means for them to be actual is, once again, to be subjective and physical, although their subjectively physical nature differs from that of perceptual consciousness.

4. Honderich's contention that there is more to reality than what is objectively physical has admittedly a strong allure. Yet, even at the end of Actual Consciousness, many important questions remain unanswered. Precisely what is the relationship between the subjectively physical and the objectively physical? How different are subjectively physical worlds from objectively physical world? Are subjective properties really 'different in kind' from objective properties (239)? If so, is a subjectively physical world one that is worth its name? Finally, on the basis of his account, what progress have we made in regards to understanding consciousness? Does the distinction between subjectively physical and objectively physical solve the difficulties of consciousness? Or does it merely mask them, as I am inclined to think, under different labels and guises? I do not have satisfactory answers to offer on behalf of Honderich to those questions. Actual Consciousness often feels like a labyrinth made out of words, one that is devoid of Ariadne's thread.

ANDREAS ELPIDOROU University of Louisville Lonisville, KY 40204 andreas.elpidorou@louisville.edu 